\title{
İsrail'in Devlet Kurgusu Güvenli Bir Yahudi Yurdu mu? Yoksa Güvenlikçi Bir Yahudi Devleti mi?
}

Is the Fiction of the State of Israel

\section{Zafer BALPINAR*}

$\ddot{O} z$

Bu çalışma Ísrail Devleti adıyla kurulan Yahudi devletinin bir güvenli yurt arayışından güvenlikçi bir yurt modeline dönüşüp dönüşmediği ele almaktadır. Bu çerçevede, Yahudiler için güvenliğin teminatı olacak bir devletin kurulmasına zemin oluşturacak biçimde, devletin yapısal özü, devletin ilhamı, devletin yaşam sahasi ve devletin sosyal bileşenlerinin meydana getirdiği altyap ortaya konmakta; daha sonra bu kapsam üzerinden bir analiz yapılmaktadır. Çalışma, devlet kurgusunun yapılışında David Ben Gurion'un etkin liderliği altında bir Yahudi siyasi ve askerî elitinin düsünce, karar ve icraatlart temel olarak kabul etmektedir. Çalışma, tarihsel süreç olarak çatışma ortamıla şekillenen beka arayışı ile devletleşme arasındaki ilişkiye odaklandığından, İsrail Devleti ile ilgili temel parametrelerin belirlendiği devletin kuruluşunun hemen öncesini ve hemen sonrasinı kapsamaktadir.

Anahtar Kelimeler: Israil, Güvenlik, Beka, Devlet, Yahudi.

\section{Abstract}

This study examines whether the Jewish state established in the name of the State of Israel has transformed from a search for a safe homeland to a security-minded Jewish state. In this frame, the infrastructure that includes the state's constructional essence, the state's inspiration, the state's living space and the state's social composition is set forth in a fashion of providing a ground for

Yrd. Doç. Dr., Mehmet Akif Ersoy Üniversitesi, Uluslararası İlişkiler Bölümü, e-posta: zbalpinar@mehmetakif.edu.tr.

Geliş Tarihi / Received : 26.05.2017

Kabul Tarihi / Accepted : 14.09.2017 
154

Güvenlik Stratejileri

Y11: 13

Say1: 26

founding a state that will be safety guarantee of Jews. An analysis is conducted through this scope. The study is based on the ideas, decisions and actions of Jewish political and military elite under the active leadership of David Ben Gurion in the construction of the state fiction. Because the study focuses on the relationship between a historical survival aspiration that is shaped by the conflict environment and the nationalization progression, it covers the immediate before and after of the foundation of the state in which the basic parameters concerning the State of Israel are determined.

Keywords: Israel, Security, Survival, State, Jews.

\section{Giriş}

Yahudi tarihinin neredeyse tamamı sürgün, yok edilme, dışlanma ve sosyal izolasyonla tanımlanabilir. Musa liderliğinde Mısır'dan çıkışla birlikte başlayan süreçte bir toprağa sahip olma ve bu toprakta güven içinde barınma meselesi hep yaşamsal konumda olmuştur. Bugünkü Filistin topraklarında Davut ve Süleyman devirlerinde millî ve dinî nitelikteki krallıkları, kurdukları yerleşik medeniyetin zirvesini teşkil etmiştir. Ancak Süleyman'ın ölümünden sonra (M.Ö. 933) İsrail ve Yahuda krallıkları olarak ikiye ayrılmıştır. İlkinin Asurlular (M.Ö. 722) ikincisinin de Babilliler (M.Ö. 586) tarafından yıkılmasıyla sürgün hayatı başlamıştır. Babil sürgününden sonra Pers Kralı Darius'un Babillileri yenmesiyle (M.Ö. 538) ancak Kudüs'e dönebilen Yahudiler, M.S. 70 yılında tekrar Romalılar tarafindan bölgeden sürgün edilmiştir. Bu sürgün dönemi İsrail Devleti'nin 1948' de kuruluşuna değin sürmüştür.

Yahudilerin 12. ile 19. yüzyıllar arasında katliam, zulüm, ötelenme ve gettolaştırılmaya maruz kaldıkları süreçte, güvenlik, en çok ihtiyacını hissedilen duygu olmuştur. Avrupa'daki Rönesans hareketi Yahudi Aydınlanma Hareketi'nin (Haskala) ortaya çıkışını sağlamıştır. Amerikan Bağımsızlık Bildirgesi ve Fransız Devrimi de Yahudilerin bir kimlik olarak tekrar tarih sahnesine geri dönmeleri fikrini yeşertmiştir. Ancak Yahudileri kendi devletlerine sahip olma düşüncesine iten husus dönemin coşkulu söylemi olan milliyetçilik değil, güvenlik duygusu olmuştur.

1880 yılında Rusya'da Yahudilere karşı başlatılan kıyım dönemi, ilk siyonist grupların (Hovevei Zion, Bilu vs.) ortaya çı1kışını 
sağlamıştır. Bu gruplar, ata toprağı olarak gördükleri Filistin'e göçü teşvik ve organize ederek, orada tarımsal yerleşimler kurmayı eylem olarak benimsemiştir. Çoğunun motivasyonu siyasi olmamıştır.

Güvenli bir Yahudi yurdu arayışındaki motivasyonlardan biri de, Dreyfus davası ve o davayı bir gazeteci olarak izleyen Theodor Herzl olmuştur. Herzl, bu dava sürecinde Yahudilerin sadece Yahudi oldukları için olumsuz ayrımcılığa tabi tutulduklarını müşahade etmiştir. Dava sürecinde sıklıkla duyulan "Yahudilere ölüm" sloganı Herzl'i düşünce dünyasını esir almıștır. Herzl, artık Yahudilerin kendi güvenli yurtlarını kurmalarını zamanının geldiğini ele alan manifesto niteliğindeki "Yahudi Devleti" isimli kitabını 1896' da yazmıştır.

Güvenli Yahudi yurdu arayışı doğrultusunda 16 ülkeden gelen 197 delege ile Herzl'in başkanlığında ilk büyük Yahudi siyasi organizasyonu olan 1. Siyonist Kongre, 1897'de İsviçre'nin Basel kentinde toplandi. Yahudi yurdunun gerekliliği konusunda hemfikir olan delegeler, bu yurdun neresi olması gerektiği konusunda başta Herzl olmak üzere farklı fikirlere sahiptiler. Herzl'in odak noktası, bu yurdun neresi olacağından ziyade, bir an önce güvenli bir toprak üzerinde sadece kendilerine ait olacak ve güvenliklerini sağlayacak bir devlete kavuşmaktı. Müstakbel devletin yeri ile ilgili öneriler ve tartışmalar, Herzl'in ani ölümünün hemen sonrasında 1904'te düzenlenen 7. Siyonist Kongre' de Filistin kararının alınmasıyla sona erdi. Bundan sonrası artık zaman, zemin, imkân ve eylem üzerinden belirlenecekti.

$\mathrm{Bu}$ çalışma bu aşamadan itibaren bir Yahudiler için güvenliğin teminatı olacak Yahudi devleti kurulmasına yönelik olarak eylemleri ele alarak, amaçlanan güvenli Yahudi yurdunun esaslarını belirlemekte; sonra devlet kurgusundaki güvenlikçi politikayı açığa çıkarmaya çalışarak, Yahudi devletinin bir güvenli yurt arayışından güvenlikçi bir Yahudi devleti modeline dönüşüp dönüşmediği ele almaktadır. Çalışmada devlet kurgusunun yapılışında David Ben Gurion'un etkin liderliği altında bir Yahudi siyasi ve askerî elitinin düşünce, karar ve icraatları temel olarak kabul edilmektedir. Çalışma, tarihsel süreç olarak çatışma ortamıyla şekillenen beka arayışı ile devletleşme arasındaki ilişkiye odaklandığından, İsrail Devleti ile ilgili temel parametrelerin belirlendiği devletin kuruluşunun hemen öncesini ve hemen sonrasını kapsamaktadır. 
156

Güvenlik

Stratejileri

Y1l: 13

Say1: 26

\section{Güvenli Yahudi Yurduna Giden Süreç}

Filistin'de bir Yahudi yurdu teşkil edilmesine dair düşünce, Filistin toprakların Yahudilere ait olduğu kabulü üzerine oturuyordu. ${ }^{1}$ Ancak 1. Siyonist Kongre'den beri Filistin'de bir devletin kurulmas1 yönünde adım atılamaması sorunu kronikleştirmişti. Balfour Deklarasyonu'nun (1917) ilan edilmesiyle birlikte, Birinci Dünya Savaşı sonrasında bölgeyi mandasına alan İngiltere'nin desteğiyle bu amaç doğrultusunda sahada varlık gösterilmesi kolaylaştı. ${ }^{2}$ Böylece Filistin'de Yahudilerin inisiyatifi ele almaya yönelik çabaları görünür hale geldi. Kendi yaşam alanlarını genişletip kendi savunma altyapılarını hazırlamaya başlayan Yahudiler, önce yerel halkla çatışma içine girdi; daha sonra Yahudilerin talepkâr tutumları onları mandater ülke olan İngiltere'yle karşı karşıya getirdi. Gelinen noktada Yahudiler her iki unsura karşı tedhiş örgütü şeklindeki yapılanmalar üzerinden silahlı mücadeleye girişti. Bu süreç İkinci Dünya Savaşı'nın başlangıcına kadar devam etti. Savaş, Yahudilerin beklentilerini gerçekleştirmek için uygun kaotik ortamı ve firsatları sağlayan bir zemin olarak işlev gördü.

Dünya savaşı hızla devam ederken, Yahudi Ajansı Başkanı David Ben Gurion'un 1942'deki Biltmore Konferans1 kararlariyla Filistin'e dönmesiyle devletleşme yolunda bir ileri aşamaya geçildi. Bu aşama şu hedefleri kapsıyordu: tüm Filistin'de bir Yahudi devleti, bir Yahudi ordusu, Beyaz Kitap'nn reddi ve Yahudi Ajans1 kontrolünde sınırsız göç. Devlet fikri geri dönülmez bir şekilde netleşmişti; mesele sadece uygun zaman ve zeminin oluşmasıydı. Uygun zaman ve zemin bekleyişi, bir yandan Filistin'deki siyasi, askerî ve sosyal ortamın, diğer yandan da dünya konjonktürünün özellikle de büyük ve zengin bir Yahudi toplumu barındıran Amerika Birleşik Devletleri’nin (ABD)

${ }^{1}$ Ofira Seliktar, New Zionism and The Foreign Policy System of Israel, Croom Helm, Beckenham, 1986, p. 66.

${ }^{2}$ Shimon Peres, "Pivotal Movements", The Jewish Week, 29 November 2011, http://www.thejewishweek.com/special_sections/text_context/pivotal_moments (Erişim Tarihi: 15.04.2017). 
tutumunun izlenmesini kapsıyordu. Filistin'de uygulanan silahlı şiddet hareketlerinin İngiltere'yi sorundan kurtulmak üzere bask1 altına alması ve ABD'nin İkinci Dünya Savaşı'ndan küresel güç olarak çıkması, Yahudi devletine giden süreçte kolaylaştırıcı bir etki yaptı. ${ }^{3}$

Bir Yahudi devletine doğru olan ilerleyişte İkinci Dünya Savaşı'ndan sonra hem Nazi toplama kamplarında Yahudilerin soykırım tabi tutulma manzaraları, hem de Avrupa'nın buralarda olanlara kayıtsız kalmaları da önemli katkı sağladı. Yahudilere göre, müttefikler yapabilecek durumda olmalarına rağmen toplama kamplarına engel olmamış; bunun ötesinde İngiltere bu zulümden Filistin'e kaçmak isteyen Yahudilere göç sınırlaması getirmişti. ${ }^{4}$ Ayrıca güçlü dünya devletlerinin özellikle uluslararası kriz dönemlerinde Yahudilerden kendilerini izole etmeleri, daha fazla Yahudinin zulümden kaçabilmesi için maddi kaynak tahsis etmemeleri ve savaş döneminde mülteci olarak kabul etmemeleri, Yahudilerin sadece kendilerine ait olacak bir devlet arayışına yönelmelerinde etkili olan diğer argümanlar olmuştur. ${ }^{5}$

Başta Ben Gurion olmak üzere Yahudi siyasi ve askerî elitine göre, Yahudiler sadece Yahudi olduklarından dolayı zulme uğramıştı. $\mathrm{Bu}$ nedenle bu zulme sebep olan kimlikleri üzerinden yeniden bir hayat kuracakları Filistin dışında bir yer mümkün ve anlamlı değildi. Filistin'in tek seçenek olarak kabulü, İkinci Dünya Savaşı'nın hemen sonrasındaki konjonktür ve Filistin'de bir Yahudi devleti için çaba içinde olan aktif siyonist güçler, devlete giden yolun belirleyicisi haline geldi. ${ }^{6}$ Yahudi silahlı örgütlerinin baskısından bunaldığından ve Filistin'i yönetmenin maliyetinin gittikçe artmasından dolayı zora düşen İngiltere, bölgedeki

\footnotetext{
${ }^{3}$ Yosef Gorny, "Zionist Voluntarism in The Political Struggle: 1939-1948", Jewish Political Studies, 1990, Vol. 2, No. 1-2, 67-104, p. 80, 83.

${ }^{4}$ Tom Segev, One Palestine, Complete: Jews and Arabs Under British Mandate, Little Brown, London, 2000, p. 461.

${ }^{5}$ Efraim Karsh, Israel: The First Hundred Years, Frank Cass, London, 2004, p. 15; David S. Wyman, The Abandonment of The Jews: America and Holokost, Pantheon Books, New York, 1984, p. x, xi.

${ }^{6}$ Idith Zertal, From Catastrophe To Power: Holokost Survivors and The Emergence of Israel, University of California Press, California, 1998, p. 226.
} 
158

Güvenlik

Stratejileri

Y11: 13

Say1: 26

meselenin çözümünü Birleşmiş Milletler'e (BM) havale etti. BM'nin çözümü olan Filistin topraklarının Yahudiler ve Araplar arasında kendi devletlerini kuracak şekilde pay edilmesi karar1 (UN/GA/RES/1811947), bir Yahudi devlet için meşru çıkış noktası oldu.

Yahudiler Filistin'de devlet kurmak için bir yandan meşru bir başlangıç yapma fikri üzerinde çalışırken, diğer yandan da aynı toprak için mücadele edecekleri Arapların zayıf yönlerine odaklandılar. Yapılan tespitler, meseleyi tam olarak kavrayamamış Arapların kendilerini davayla ilişkilendirememeleri ve idealizm duygusundan yoksun olmaları üzerinde yoğunlaştı. ${ }^{7}$ Ayrıca Araplar dönemin uluslararası siyasi zemininden ve gerçekliğinden, aktörler arasındaki denge ve iletişimden uzaktı. ${ }^{8}$ Tüm bunlara ek olarak, Araplar aralarında yekpare bir örgütlenme ve liderlik geliştirememişti. ${ }^{9}$ Yahudi yönetici eliti Arapların eksik yönlerini belirledikçe, güç maksimizasyonu yoluyla amaca ulaşabileceğine karar verdi. ${ }^{10}$ Zaten Araplarla bir barış öngörülmediğinden ${ }^{11}$ Araplar üzerinde askerî baskı kurarak sonuç almaya yönelmek bir yöntem olarak benimsendi. $^{12}$

Bahse konu çerçevede, uluslararası bağlamda yürütülen siyasi çaba ve Araplara karşı sürdürülen çatışmacı süreç sonunda, 14 Mayıs 1948'de İsrail Devleti ilan edildi. Böylece hem sürgün hayatından kurtuluş, hem güvenli bir Yahudi yurdu, hem ulus kimliği, hem toplumsal özgüven, hem de Yahudiliğin vaad edilmiş topraklar gereği yerine getirilmiş oldu. Ancak bu ilan aynı zamanda Arap dünyasıyla bir savaşın da başlangıcıydı. Devlet kurulmuştu; ancak yaşayıp yaşayamayacağını

${ }^{7}$ Mike Berry and Greg Philo, Israel and Palestine: Competing Histories, Pluto Press, London, 2006, p. 18.

${ }^{8}$ Jonathan, Sless, "Blocking Peace: Britain and Israeli-Jordanian Conflict 1949-1951", (Efraim Karsh ed.), Israel: The First Hundred Years, Frank Cass, London, 2004, 77-104, p. 80.

9 Ben Soentendorp, The Dyamics of Israeli-Palestinian Relations, Palgrave McMillan, New York, 2007, p. 28.

${ }^{10}$ Alan Hart, Zionizm: The Real Enemy of The Jews, World Focus Publishing, United Kingdom, 2005, p. 26.

${ }^{11}$ Ben Soentendorp, a.g.e., p. 28-29.

${ }^{12}$ Yosef Gorny, a.g.m., p. 80. 
devletin güvenliğine ilişkin o güne kadar oluşturulan ve oluşturulacak kararlar, kabuller ve eylemler belirleyecekti. Bu kararlar, kabuller ve eylemler; aşağıdaki alt bileşenler bağlamında İsrail Devleti'nin geleceğini tanımlayacak güvenlik kavramının çerçevesini çizecektir. Bileşenlerin meydana getirdiği kavramın sahadaki yansıması olan güvenlik anlayışı ve uygulaması da İsrail Devleti'nin güvenli bir Yahudi yurdu mu, yoksa güvenlikçi bir Yahudi devleti olarak mı şekillendirildiğinin ipucunu verecektir.

\section{Güvenlik Kavramının Alt Bileșenleri}

\subsection{Devletin Yaptsal Özü}

Yahudi devletinin Filistin'de kurulmasına dair inanç o kadar güçlü idi ki, Yahudi çocuklarının İngiltere'ye transfer edilerek Nazi zulmünden tamaminın kurtarılması yerine, yarısının Filistin'e gönderilerek kurtarılmasını tercih edebilecek bir anlayış Yahudi elitlerinin düşünce dünyasına hâkimdi. Önemli olan, Yahudi halkının tarihsel beklentisinin yerine getirilmesiydi. ${ }^{13}$ Devletin kurulması, Yahudi halkının kendi kaderini kontrol etme isteği doğrultusunda mukadder görülüyordu. Ata toprăğ Filistin'e dönmek, yeni bir başlangıç olmanın yanı sıra, Yahudi toplumunun hem fiziki, hem de düşünsel sürgünden kurtulması manasına geliyordu. ${ }^{14}$

Filistin'e geri dönüş beklentisi ile şekillenen devlet özlemi başka bir toplumla birlikte yaşamayı kabul etmiyordu. $\mathrm{Bu}$ bağlamda Arapların buradaki varlığı bir anlam taşımıyordu. ${ }^{15}$ Coğrafyanın Arap kültürüne entegre olmak ise söz konusu bile değildi. Hatta başlica amaç, Yahudi toplumunu bu kültürün bir parçası olmaktan uzak tutmak, ${ }^{16}$ bu

\footnotetext{
${ }^{13}$ Herbert Adam and Kogila Moodley, Seeking Mandela: Peacemaking Between Israelis and Palestinians, Temple University Press, Philadelphia, 2005, p. 40.

${ }^{14}$ Gabriel Sheffer, Moshe Sharett: A Biography of A Political Moderate, Clarendon Press, Oxford, 1996, p. 305; David Ohana, Political Theologies in The Holy Land, Routledge, New York, 2010, p. 20.

${ }^{15}$ Slomo Ben-Ami, Scars of War, Wounds of Peace, Oxford University Press, Oxford, 2006, p. 4, 12.

${ }^{16}$ Joan Comay, Who is Who in Jewish History, Routledge, New York, 2005, p. 55.
} 
kültüre karş1 mücadele etmek ve diasporada kristalleşen Yahudi değerlerini korumaktı. ${ }^{17}$ Anılan çerçevede, devletleşme yönündeki siyasi çalışmalar iki temel talepte toplandı: evrensel haklar bakımdan tüm uluslar gibi olmak ile kimlik ve amaçlar bakımından tüm uluslardan farklı olmak. ${ }^{18}$ Amaçlanan yönde devletleşme düşüncesi devrimsel bir nitelik taşıdığından, tarihteki devrimler incelendi ve bir devrim yapılabilmesi için sosyal değişimin, değerler değişiminin ve güç kullanımının gerekli olduğu sonucuna ulaşıldı. ${ }^{19}$

$\mathrm{Bu}$ parametreler çerçevesinde Yahudilerin birlikte güvenli ve onurlu bir yaşam alanı oluşturma arayışı anlamına gelen "Klal Yisrael"(Yahudilerin dünya çapında birliği) anlayışı, devlet inşasının temeli olarak kullanıld1. ${ }^{20}$ Bahse konu bağlamda devlet, sadece teşkilatlanmış bir hükümet yapısı değildi. Devlet, güvenlik içinde özgürlük, bağımsızlık ve özgürce yeni şeyler yaratabilmek demekti. ${ }^{21}$ Bunu sağlayacak olan ise, tüm Yahudilerin içinde yaşayacağı ve sadece Yahudilere ait bir ulus devletti. ${ }^{22}$

Dağınık halde bulunan bir halkın yeni bir ulus şeklinde inşası, en iyi biçimde devlet teşkilatlanması yoluyla yapılabilirdi. Ben Gurion bu teşkilatlanmaya geniş ve güçlü, her şeyi içine alan otorite anlamına gelen "mamlachtiut"adını verdi. ${ }^{23}$ Bu yapı içinde tüm toplumu harekete

${ }^{17}$ Daniel J. Schroeter, “A Different Road to Modernity: Jewish Identity in The Arab World", Howard Wettstein (ed.), Diasporas and Exiles, University of California Press, Berkeley, 2002, 150-163, p. 153.

${ }^{18}$ Eran Kaplan, The Jewish Radical Right, The University of Wisconsin Press, Wisconsin, 2005, p. 33, 117.

${ }^{19}$ David Ohana, a.g.e., p. 31.

${ }^{20}$ Yosef Gorny, "Klal Yisrael: Halakha to History", Eliezer Ben-Raphael, Yosef Gorny, Yaacov Roi (ed.), Contemporary Jewries, Brill, Leiden, 2003,13-22, p. 12, 21.

${ }^{21}$ Eliezer Don-Yehiye, "Political Religion in A New State: Ben Gurion's Mamlachtiyut", S. Illan Troen, Noah Lucas (ed.), Israel: The First Decade of Independence, State University of New York Press, Albany, 1995, 171-192, p. 191.

${ }^{22}$ Yosef Gorny, "Zionist Voluntarism in The Political Struggle: 1939-1948”, p. 687.

${ }^{23}$ Ze'ev Drori, "Utopia in Uniform”, S. Illan Troen, Noah Lucas (ed.), Israel: The First Decade of Independence, State University of New York Press, Albany, 1995, 594-613, p. 595. 
geçirmek ve bir amaca yöneltmek mümkündü. Böylelikle toplumun

tüm yașamsal alanlarına ve değerlerine yeni normlar getirilmesi amaçlanıyordu. $^{24}$ Kendisinden beklenenler bağlamında bu yapı, toplumun hatta ulusun üstüne yerleştirildi, toplumun bir sadakat ve itaat odağı șeklinde konumlandırıldı. ${ }^{25}$ Öngörülen bu yap1 içinde oluşturulmak istenen İsrailli kimliği, merkeze yerleştirildi ve bireyin kaderi devletinkiyle özdeşleştirildi. ${ }^{26}$

Yahudi müşterek değerleriyle şekillenecek toplumsal birlik ve devletin bütünlüğü önemsediğinden, tüm potansiyel güç kaynakları devletin altında toplandı. Yapılan devlet kurgusunun hedefi, aşırı güçlü ve merkezî bir devletin kamu hayatının tüm alanlarına ve özel hayatın da birçok alanına erişmesiydi. Anılan kurgu bağlamında, birlik anlayışı ise merkezî bir devletin yakın gözetimi altında sosyal/politik kurum ve yapıların birliği anlamını taşıyordu. "Mamlachtiut" şekil itibarıyla sekülerdi, ama içeriği oldukça derin tarihî arka plan, mesihçi referans ve dinî motifler barındırıyordu. ${ }^{27}$ Zira Yahudi devletinin, idari, askerî ve diplomatik bir yap1 olmanın ötesinde, sosyal bir yap1 olarak siyonizmi ve dinî motifleri barındırması iç tutarlılı̆̆ bakımından önemliydi. ${ }^{28}$ Güvenliğin birliktelik ve yekpare hareket edebilme kabiliyeti ve kapasitesi olduğu düşünüldüğünde, devlet için öngörülen her unsurun aynı zamanda güvenliğin de bir bileşeni olduğu görülmektedir.

\subsection{Devletin İlhamı}

Devletleşme sürecinde Siyonizme yüklenen anlam, Yahudilerin Filistin topraklarında bir devlet ve ulus inşa etmesiydi. Ayrıca Siyonizm,

\footnotetext{
${ }^{24}$ S. Illan Troen and Noah Lucas, "An Introduction to Research on Israel's First Decade", S. Illan Troen, Noah Lucas (ed.), Israel: The First Decade of Independence, State University of New York Press, Albany, 1995, 1-28, p. 2.

${ }^{25}$ Ilan Peleg, "Israel As A Liberal Democracy: Civil Rights in The Jewish State", Review Essays in Israel Studies, State University of New York Press, Albany, 2000, 63-80, p. 72.

${ }^{26}$ Clive Jones and Emma C. Murphy, Israel: Challenges to Identity, Democracy and The State, Routledge, New York, 2002, p. 20.

${ }^{27}$ Patricia J. Woods, Judicial Power and National Politics, State University of New York Press, Albany, 2008, p. 63, 66, 71.

${ }^{28}$ David Ohana, a.g.e., p. 24.
}

Güvenlik Stratejileri

Y11: 13

Sayı: 26 
her Yahudinin içindeki istek, arzu, yetenek ve niyeti yoğurarak güçlendirmesi ve onu yüksek bir davaya kanalize etmesiydi. ${ }^{29} \mathrm{Bu}$ bağlamda ön plana çıkan husus, kendini bu ülküye adamış bireyleri var etmek, sonra da harekete geçirmekti. ${ }^{30}$ Her ne kadar devlet kurgusu Yahudilerin müstakbel ülkeleri için yapacağı fedakârlığa ve harcayacağı çabaya dayandırılsa da; esas odaklanılan konu, her türlü değerin üzerinde yer alacak ve her şeyi kapsayacak bir devlet anlayışıydı. Ancak böyle bir devlet Yahudilerin hep özlemini çektiği güvenlik ortamını sağlayabilirdi. ${ }^{31}$

Ortaya konan çerçevede, bir Yahudi devletinin oluşturulabilmesi ancak azimli Yahudilerin şekillendirdiği bir toplumla oluşturulabilirdi. ${ }^{32}$ Buna göre, diasporanın pasif ekonomi, toplum ve kültür anlayış1 değiştirilerek, yeni bir disipline sahip yeni bir İbrani toplumu teşkil edilecekti. ${ }^{33}$ Kurgulanan toplum, geleceğe yönelik tüm amaçları gerçekleştirebilecek şekilde realist, pragmatist ve materyalisttir. Ancak, devletleşmeye giden süreçte materyalizm unsuru ifade edilmekten kaçınılmış; onun yerine birlikteliğe katkı sağlayacak manevi unsurlar ön plana çıkarılmıştır. ${ }^{34}$

Filistin topraklarına gitmek için salt sürgünde olma ve zor şartlar altında yaşama dürtüsü yeterli değildi. Yahudi dinî temalarını/ değerlerinin siyasi etkisine ve birleştirici gücüne ihtiyaç vardı. Birliktelik duygusunun oluşturulması öncelikli hedefti. Bunu yapacak etmen, diasporayı Filistin topraklarına çekebilmeli ve toplumun kendi özünden kaynaklanmalıydı. Yahudilik, işte bu konsolidasyon aracıydı. $\mathrm{Bu}$ nedenle dinî değerler ve motifler, ulusun inşasında bir çeşit harekete geçirici mit haline getirildi. Böylece yerleşimler için çağrı yapmak ve toplumun farklı kesimlerini bir arada tutmak kolaylaştı. Öte yandan, bu

${ }^{29}$ Eran Kaplan, a.g.e., p. 73, 137.

${ }^{30}$ David Ben-Gurion, Rebirth and Destiny of Israel, Polyglot Press, New York, 1954, p.5-6.

${ }^{31}$ Patricia J. Woods, a.g.e., p. 61.

${ }^{32}$ Efraim Karsh, a.g.e., p. 15; Shabtai Teveth, Ben-Gurion: The Burning Ground, 1886-1948, Houghton Mifflin, Boston, 1987, p. 389.

${ }^{33}$ Eran Kaplan, a.g.e., p. 112.

${ }^{34}$ David Ben-Gurion, a.g.e., p. 426. 
yaklaşım İsrail Devleti'nin varlığını "Tanrı'nın yeryüzündeki eylemi” olarak sunabilmeyi mümkün kıldı. Ayrıca kutsal metinlerin dili olan İbranice'nin ulusal dil olmasına imkân tanıdı ve özgün bir kimliğin oluşmasına katkı sağladı. Bu yaklaşım, din unsurunun güvenlik arayışının Güvenlik Stratejileri altyapısına eklemlemesinin önünü açtı. Bu yapılırken, konsolidasyonun dozunu arttırmak için, tek tipleştirilmesi zor olan diaspora Yahudiliği Say1: 26 yerine, özde daha bağlayıcı olduğu düşünülen Eski Ahit Yahudiliği kullanıldı. Bu kapsama genel Yahudi tarihi de dâhil edildi. Hem Yahudiliğin, hem de seküler-tarihî-ulusal sembollerinin ve değerlerinin bir arada kullanılmak istenmesinin nedeni, dindar ve laik kesimleri aralarında bir cepheleşme olmadan, devlet çatısı altında bir araya getirmektir. ${ }^{35}$ Eski Ahit Yahudiliğinin ön plana çıkarılmasının bir diğer amacı da, dünya Yahudilerinin bu mücadeleye destek vermesini sağlamaktır. ${ }^{36}$

Bahse konu doğrultuda devletleşme öncesindeki amaç, Filistin'deki Yahudi toplumundaki farklı görüşteki kesimleri arasında işlevsel bir birliktelik kurmaya çalışmak olmuştur. ${ }^{37}$ Devlet sonrası dönemde de farklılıkların bilincinde olarak, Yahudi toplumundaki bölünmeleri aşmak ve oluşan birliği sağlamlaştırmak için yeni bir ulusal bilinç etrafında yeni vatandaşlık kimliğine odaklanılmıştır. ${ }^{38} \mathrm{Bu}$ yeni kimlik, derin bir dinî-tarihî geçmişten beslenen ve kader ortaklığında bir araya gelen bir Yahudi bilincini barındırmaktadır. ${ }^{39}$

Çerçevesi çizilen devlet anlayışı, Filistin'de tarihi olarak varolagelmiş Yahudi toplumunu kurguya daha az dâhil ederken, daha fazlasıyla Filistin'e göç olgusu üzerine yoğunlaşmıştır. ${ }^{40}$ Buna göre,

\footnotetext{
${ }^{35}$ David Ohana, a.g.e., p. 15-16, 19, 21; Patricia J. Woods, a.g.e., p. 64, 66, 69, 70-71, 177.

${ }^{36}$ S. Illan Troen and Noah Lucas, "An Introduction to Research on Israel's First Decade", p. 1.

${ }^{37}$ Derek J. Penslar, Israel in History, Routledge, New York, 2007, p. 33.

${ }^{38}$ S. Illan Troen and Noah Lucas, a.g.m., p. 8; Clive Jones and Emma C. Murphy, a.g.e., p. 20.

${ }^{39}$ Nathan Rotenstreich, Zionism: Past and Present, State University of New York Press, Albany, 2007, p. 31.

${ }^{40}$ Eliezer Ben-Rafael, "The Kibbutz in 1950s: A Transformation of Identity”, S. Illan
} 
164

Güvenlik

Stratejileri

Y11: 13

Sayı: 26

yeni Yahudi ulusu dünyanın her yerinden katılımla meydana gelecektir. $\mathrm{Bu}$ sadece dayanışma ruhunun yaratılması anlamında değil; ülke savunması için yeterli caydırıcılığı oluşturacak insan gücüne sahip olmak anlamında da önemsenmiştir. ${ }^{41}$ Yahudi halkının yeniden tarihî ülkelerine dönüşünü ele alan Filistin'e göç hikâyeleri siyonist mitolojinin oluşturulmasında kullanmıştır. ${ }^{42}$ Böylece bir ruh ve misyon yüklenen göçmenler, devlet ideolojisine ve kurgulanan yapıya enjekte edilmiştir. Arap tehdidi de bu yapının güçlendirilmesi için kullanılmıştır. ${ }^{43}$

\subsection{Devletin Yaşam Sahası}

1947 yllında bir taksim planının hedeflenen amaca götürüp götüremeyeceği konusunda, Ben Gurion'un başkanı olduğu Yahudi Ajansı yönetimi ile Filistin'deki Yahudiler arasında görüş ayrıllı̆g ortaya çıktı. Radikal gruplar çatışma yoluyla mümkün olduğunca en ileri sınırları elde etmeyi amaçlarken; Ben Gurion Filistin'e uluslararas meşruiyeti olan bir yolla yerleşip sınırların geleceğine konjonktüre göre karar vermeyi tercih ediyordu. Ben Gurion'un yoğun çabas1 sonucu, meşruiyet sağlayacak olan taksim kararı yönünde hareket edilmesi kabul edildi. ${ }^{44}$ Sorun tarafların şu konularda fikir birliğine varmasıyla aşılabildi: sınırları tanımsız bir Yahudi devleti ilan edilmesi, göçe ve yerleşim yerleri kurulmasına devam edilmesi. ${ }^{45}$

Aslında, taksim planıyla Yahudi devletine tahsis edilen bölgede $\% 40$ oranda Yahudi olmayan nüfus bulunmaktaydı ve bu oran Yahudi egemenliğini tesis etmeye sorun teşkil etmekteydi. İstikrarlı bir devletin

Troen, Noah Lucas (ed.), Israel: The First Decade of Independence, State University of New York Press, Albany, 1995, 265-278, p. 270.

${ }^{41}$ Ariel L. Feldestein, Ben-Gurion, Zionism and American Jewry 1948-1963, Routledge, New York, 2006, p. 136-159; Nathan Rotenstreich, a.g.e., p. 34.

${ }^{42}$ Eran Kaplan, a.g.e., p. xii; Zertal, a.g.e., p. 224; David Ohana, a.g.e., p. 17.

${ }^{43}$ Neil Lochery, Why Blame Israel?: The Facts Behind The Headlines, Icon Books, Cambridge, 2004, p. 16.

${ }^{44}$ Joseph Heller, The Birth of Israel 1945-1949: Ben Gurion and His Critics, University of Florida Press, Gainnesville, 2003, p. 90.

${ }^{45}$ Avi Shlaim, The Iron Wall: Israel and Arab World, W.W. Norton, New York, 2001, p. 95-98. 
İsrail'in Devlet Kurgusu

Güvenli Bir Yahudi Yurdu mu? Yoksa Güvenlikçi Bir Yahudi Devleti mi?

en az $\% 80$ Yahudi nüfusuna sahip olması gerekliydi. ${ }^{46} \mathrm{Bu}$ duruma rağmen taksim planının kabul edilmesindeki amaç, BM'nin belirlediği sinırları değiştirmek üzere askerî gücü takviye etmek için zaman kazanmakt1. ${ }^{47}$

Bir yandan devletleşme süreci taksim planı üzerinden yürütülürken, diğer yandan da Avrupa'daki Yahudilerin Filistin'e göç ettirilmesine odaklanılmıştı. Böylece planda yaşanacak olumsuzluklar karşısına kendi kaderini belirleme isteğinde olan kalabalık bir kitle çıkarılabilecekti. Ayrıca bu yöntemle Filistin'de daha fazla toprak beklentisi de gizleniyordu. Ancak konjonktür, Yahudi Devleti'nin BM'nin 1947 tarihli 181 sayılı Taksim Kararı yönünde ilan edilmesini gerekli kıldı. Gelinen noktada, Taksim Planı, Biltmore Konferansı programındaki maksimalist beklentilerle tam bir uyum içindeydi. ${ }^{48}$

Nihayetinde bağımsızlık-birliktelik-Filistin'e göç üçlemesi ${ }^{49}$ bağlamında kurgulanan, nihai arzuları tam olarak karşılamasa da birlik içinde kurulmuş bir devlet, 14 Mayıs 1948'de İsrail Devleti adıyla ilan edildi. Filistin'in Yahudi halkının doğum yeri, ruhani, dinî ve siyasi kimliğinin şekillendiği yer olduğu; diğer uluslar gibi kendi devletlerine sahip olmanın hak görüldüğ̈̈; Yahudi göçünün bir hak olduğu; devletin tarihî Yahudi yurdunda bir Yahudi devleti olacağı devlet ilanı metninde vurguland..$^{50}$

Devletin kimliğinin Yahudilik esasına göre tanımlanması, devletin sınırlarını belirleme politikasının da bu esasa göre ele alınmasının önünü açıyordu. Sınırlar meselesi hem yaşam alanı olması, hem de ulusal

\footnotetext{
${ }^{46}$ Jeff Halper, An Israeli in Palestine: Resisting Dispossesion, Redeeming Israel, Pluto Press, London, 2008, p. 70.

${ }^{47}$ Baylis Thomas, The Dark Side of Zionism, Lexington Books, Plymouth, 2009, p. 23.

${ }^{48}$ Yosef Gorny, "Zionist Voluntarism in The Political Struggle: 1939-1948", p. 80, 82.

${ }^{49}$ Ami Isseroff, "A Zionist Manifesto: We Must Make The Change That We Seek",
} ZioNation-Progressive Zionism and Israel Web Log, 29 February 2008, http://www.zionism-israel.com/log/archives/00000500.html (Erişim Tarihi: 15.05.2017).

50 "The Declaration of The State of Israel - May 14, 1948", Israel Ministery of Foreign Affairs, http://www.mfa.gov.il/mfa/foreignpolicy/peace/guide/pages/declaration\%20of $\% 20$ establishment\%20of\%20state\%20of\%20israel.aspx (Erişim Tarihi: 04.05.2017).

Güvenlik Stratejileri Y11: 13

Sayı: 26 
166

Güvenlik Stratejileri

Y11: 13

Sayı: 26

kimlik bakımından özel bir önem arz ediyordu ${ }^{51}$ Genel Yahudi görüşü, İsrail politikasının Yahudi devletinin sinırları olarak Eski Ahit'te belirlenen sınırları ele almasını savunuyordu. Ancak devleti kuran anlayış, Davut ve Süleyman krallıklarının yeniden kurulması düşüncesi paralelinde değil; "mamlachtiut" formatında tanımlanan devlete ilişkin bir arayış içindeydi. ${ }^{52} \mathrm{Bu}$ bağlamda amaç, yeni devletin tarihî İsrail toprağının bir kısmı üzerinde kurulmuş olması değil; devletin dinamik bir genişleme politikası benimsemesine yönelikti. ${ }^{53} \mathrm{Bu}$ paralelde devletin ilanında sınırlarına ilișkin bir ifade kullanmamıș; ülkenin sınırlarını belirlemek için bir fikir birliği oluşturulması arayışında olunmamıştır. ${ }^{54}$

Yahudi devletini kuran anlayışa göre sınırlar esnek ele alınmalı; tarihsel gelişmelerin, bölgesel ve uluslararası şartların doğasına ve gereğine göre şekillenmeliydi. ${ }^{55}$ Bölgesel şartlardan kastedilen, sınırlar ve toprağa ilişkin politikaların çıkış noktasının çatışmalar olması gerektiğidir. Başka bir deyişle, Yahudilerin kendine duydukları özgüven ve çatışmaların sonuçları devletin sınırlarını belirleyecektir. Ele geçirilen toprakların İsrail' in kontrolünde kalması ise en temel gereklilik olarak belirlenmiştir. ${ }^{56}$

Toprak bakımdan daha fazla genişleme beklentisi, İsrail Devleti'nin ilanından sonra Birleşik Arap Ordusu'nun İsrail'i ortadan kaldırmak için 15 Mayıs 1948'de saldırıya geçmesiyle hayata geçti. Savaş, 1949 yılında İsrail'in Filistin toprağının \%78'ini (daha öncesindeki Taksim Planı'yla Yahudi devletine Filistin toprağının \%56'sı bırakılmaktaydı) elde etmesiyle sonuçlandığında, devleti kuran anlayışın öngörüsü ve politikası amacına ulaşmış oldu. Aynı politikanın devamı olarak, savaş sonrasında

${ }^{51}$ Ofira Seliktar, a.g.e., p. 69.

${ }^{52}$ Israel Shahak, Jewish History, Jewish Religion, Pluto Press, London, 1994, p. 11, 14.

${ }^{53}$ Ghada Karmi, Married to Another Man: Israel's Dilemma in Palestine, Pluto Press, London, 2007, p. 23.

${ }^{54}$ Kameel B. Nasr, Arab and Israeli Terrorism: The Causes and Effects of Political Violence 1939-1999, Mc Farland and Company Publishers, North Carolina, 1997, p. 24.

${ }^{55}$ Nur Masalha, Imperial Israel and The Palestinians, Pluto Press, London, 2000, p. 6.

${ }^{56}$ Slomo Ben-Ami, a.g.e., p. 12, 25, 34, 37. 
ateșkes hatlarının belirlenmesi dıșında Arap devletleriyle sınırların 1948 Savaşı'nda alınamayan \%22'lik kısmın ele geçirilmesi oldu. ${ }^{58}$

Savaş sonrasında ele geçirilen toprakların İsrail Devleti'nin hâkimiyet sahasına dâhil edilmesi süreci, "Filistin" yerine "İsrail", "Filistinliler" yerine" İsrailli Araplar" ifadelerinin kullanılmasıla başladı. ${ }^{59} \mathrm{Bu}$ süreç, Filistin kasaba ve köylerinin isimlerinin Yahudi tarihindeki veya Eski Ahit'teki karşılıklarıyla değiştirilmesiyle devam etti. ${ }^{60}$ Daha sonra "Yargılama Yetkisi ve İktidar Sahası Kanunu" ile İsrail ordusu tarafindan ele geçirilen topraklarda İsrail yasalarının tümünün uygulanması sağlandı. "T1 "Terkedilmiş Bölgeler Kanunu" ile de İsrail ordusu tarafindan ele geçirilen, İsrail'e teslim edilen veya terkedilmiş tüm yerlerindeki her şey terkedilmiş sayılarak buralardaki her şeye ilişkin tasarruf hakkı İsrail hükümetine verildi. ${ }^{62}$ Böylece güvenliğin tanımlanmasında kullanılabilecek saha unsurları Yahudilerin eline geçti.

\subsection{Devletin Sosyal Bileşenleri}

Sınırlar meselesi, hem devletin coğrafi genişlemesi, hem de Yahudilik kabullerine göre sahip olunması gereken topraklar bağlamında devlet kurgusuna dâhil oldu. Sinırlar meselesi devletin Yahudi devleti olarak ilan edilmesini, Yahudilere güvenli bir yurt sağlanmasını ve

\footnotetext{
${ }^{57}$ Ami Gluska, The Israeli Military and The Origins of 1967 War: Government, Armed Forces and Defence Policy 1963-1967, Routledge, New York, 2007, p. 23.

${ }^{58}$ Avi Slaim, Conclusions Across The Jordan, Colombia University Press, New York, 1988, p. 465.

${ }^{59}$ David Ben-Gurion, Israel: A Personel History, American Israel Publishing Co.,Tel Aviv, 1971, p. 100.

${ }^{60}$ Ghada Karmi, a.g.e., p. 18.

${ }^{61}$ Elia Zureik, "Constructing Palestine Through Surveilence Practices", The Partitaion Motifs in Contemporary Conflicts, SAGE Publications, California, 2007, 122-142, p. 131.

${ }^{62}$ Ruling Palestine: A History of The Legally Sanctioned Jewish-Isareli Seizure of Land and Housing in Palestine, The Center for Housing Rights and Evictions (COHRE) - Source Center for Palestine Residency and Refugee Rights (BEDIL) Publications, 2005, p. 38-40.
} 
168

Güvenlik

Stratejileri

Y1l: 13

Sayı: 26

diasporanın bu devlete bağlanabilmesini bir araya getiriyordu. $\mathrm{Bu}$ bileşenler, aynı zamanda devletin güvenliği sorununu ve bu sorundan hareketle çözüm yollarını tanımlıyordu.

Buna göre, Filistin'de nitelikli genişleme, sınırların Yahudi karakterinin korunarak sürekli ileriye ötelenmesiydi. Zira devletleşme fikri, Filistin'de yerel halk temizlenmedikçe bir Yahudi devletinin yaratılamayacağını esas alıyordu. ${ }^{63}$ Aynı bağlamda, Arap bölgeleri İsrail'in geleceği için tehdit olarak tanımlanıyor; Yahudi devletinin mümkün olduğunca az Arap nüfusu barındırması isteniyordu. ${ }^{64}$ Ayrıca Yahudi devletinden Arapların transferinin daha fazla ulusal konsolidasyon sağlayacağı vurgulanıyordu. Bu nedenle Filistin'de bir Yahudi devletinin varlığını kabul etmeyen Arapların zorunlu transfer normal bir gereklilik olarak ele alınıyor ve bunda gayriahlaki bir şey görülmüyordu. $\mathrm{Bu}$ çerçevede politika, Filistinlilerin geri dönüşünün asla kabul edilmemesi üzerine kuruldu. ${ }^{65}$ Bunun ötesinde ise, şartlar oluştuğunda ve yeterli güce sahip olunduğunda, Arapların sürülmesi hedeflendi. ${ }^{66}$ Arapların sürülmesi, askerî kararlılığın bir göstergesi olarak da değerlendiriliyordu. ${ }^{67}$

1948 Savaşı, 700.000 Filistinliyi topraklarını terk etmeye zorladığından siyasi elitin bahsedilen düşüncelerini uygulamak için de bir ortam oluşturdu. ${ }^{68}$ Her ne kadar başlarda mültecilerin dönüşü Araplarla barışın tesisine endekslense de; daha sonra barış tesis edilse

${ }^{63}$ Jonathan Cook, Disappearing Palestine: Israel's Experiments in Human Despair, Zed, London, 2008, p. 28, 101.

${ }^{64}$ Mordechai Bar-On, In Pursuit of Peace: A History of The Israeli Peace Movement, United States Institute of Peace, Washington D.C., 1996, p. 4-5; Slomo Ben-Ami, a.g.e., p. 37.

${ }^{65}$ Benny Morris, Righteous Victims: A History of The Zionist-Arab Conflict, 18812001, Knopf, New York, 1999, p. 141-142, 144; Jeff Halper, a.g.e., p. 79.

${ }^{66}$ Shabtai Teveth, Ben-Gurion and the Palestinian Arabs: From Peace to War, Oxford University Press, Oxford, 1985, p. 189.

${ }^{67}$ Simha Flapan, The Birth of Israel: Myths and Reality, Croom Helm, London, 1987, p. 90.

${ }^{68}$ Gregory Harms and Todd M. Ferry, The Palestine-Israeli Conflict, Pluto Press, London, 2008, p. 99-100. 
bile mültecileri geri dönüş yerinin İsrail değil, Arap ülkeleri olmas1 fikri benimsendi. ${ }^{69}$ Arapların terk ettikleri yerlere dönmelerine izin verilemeyeceği; bunun savaş ve sonrası ile sınırlı olmadığı; süreklilik arz edeceği vurgulandı. ${ }^{70}$ Böylece Arapsız bir Filistin coğrafyası anlayışı, Güvenlik Stratejileri 1948'in ikinci yarısında şekillendi ve 1949 yılında da daha sonra hiç değişmeyecek tutarlı resmî söyleme dönüştü. ${ }^{71} \mathrm{Bu}$ yaklaşım çerçevesinde, Filistin'deki Araplar Yahudilerin homojenliğine zarar veren "yakın tehlike" olarak nitelendirildi. ${ }^{72}$ Savaş sonrasında yerlerini terketmeyerek İsrail vatandaşı olan Filistinliler de (İsrailli Araplar) sadece savaş zamanında değil, barış zamanında da tehlike olarak görülmeye devam edildi. ${ }^{73}$

Filistin'deki Arapların ötelenmesinden oluşan boşluğa ve sınır bölgelerine hem Holokosttan kurtulmuş olan Yahudi göçmenler, hem de Arap ülkelerinden gelen Yahudi göçmenler yerleştirildi. Böylece Arapların saldırıları bağlamında, hem bu kesimler üzerinden yok edilme duygusu canlı tutuldu; hem de bu kesimlerin saldırganlara karşı şiddetli tepkisi Yahudi toplumu motive edilmek için kullanıldı. ${ }^{74}$

\footnotetext{
${ }^{69}$ Howard Sachar, A History of Israel: From The Rise of Zionism to Our Time, Knopf, New York, 1986, p. 439-440.

${ }^{70}$ Shulamit Carmi and Henry Rosenfeld, "The Time When The Majority in The Israeli Cabinet Decided 'Not to Block The Possibility of The Return of The Arab Refugees' and How and Why This Policy Defeated", Michael Saltman (ed.), Land and Territoriality, Berg, Oxford, 2002, 37-69, p. 52.

${ }^{71}$ Jacob Tovy, Israel and The Palestinian Refugee Issue, Routledge, New York, 2014, p. 1, 272.

${ }^{72}$ Peter L. Hahn, Caught in Middle East: US Policy Towards The Arab-Israeli Conflict 1945-1961, The University of North Carolina Press, Chapel Hill, 2004, p. 100; David Tal, The War in Palestine 1948: Strategy and Diplomacy, Routledge, New York, 2004, p. 104.

${ }^{73}$ Benny Morris, Israel's Border Wars, 1949-1956, Clarendon Press, Oxford, 1993, p. 164.

${ }^{74}$ Idith Zertal, Israel's Holokost and The Politics of Nationhood, Cambridge University Press, Cambridge, 2010, p. 177.
} 
Güvenlik

Stratejileri

Y11: 13

Say1: 26

\section{Analiz: Güvenli Bir Yahudi Yurdu mu Yoksa Güvenlikçi bir Yahudi Yurdu mu?}

Theodor Herzl'in Yahudiler için güvenli bir toprağa duyulan ihtiyacı, bu toprağın niteliğine özel bir atıf yapmamıştır. Özellikle Avrupa ve Rusya coğrafyası bağlamında Yahudilerin karşı karşıya oldukları yaşamsal tehdidin geldiği aşama, Herzl'i gerçek anlamda fiziki güvenlik ihtiyacının karşılanması arayışına itmiştir. $\mathrm{Bu}$ kapsamda, güvenlik kavramı, Herzl'e göre, Yahudilerin canlarının güvenceye alınmasını sağlayacak bir toprağa sahip olmaktır. 19. yüzyılın sonu itibarıyla devlet ihtiyacı geleceğe yönelik idealist bir kurgu değil; otantik bir içerikle yani o anda olan ve o ortama özgü şekilde tanımlıdır.

Herzl'e göre, Yahudiler kimliklerinden dolayı yakın tehdide maruz kalmaktadır. Yoksa Yahudilerin bir devlete sahip olma arayışları bağlamında kendilerine özel ve ideal şartları ortaya koyan bir güvenlik kavramını tanımlamalarından bahsedilmesi dönemin gerçekleriyle örtüşmemektedir. Zira Yahudi olarak adlandırılabilecek bir toplum, her yere ve uzun bir zamandan beri dağılmış olduğundan, tek bir Yahudi protipi üzerinden yola çıkarak kurgu oluşturulması olanaklı değildir. $\mathrm{Bu}$ nedenle, tek bir Yahudi halk1 ve kimliğinden bahsedilemeyeceği için, bunlar aynı coğrafyada tek bir toplum haline getirilmediği sürece güvenlik kavramının bütün bir diasporanın gelecek beklentisine göre kurgulanması gerçekçi görülmemiştir. Güvenliğin bir toplum için tanımlanabilmesi amacıyla o toplumun birliktelik ilişkilerinin ve amacının belirlenmesi gereklidir.

İsrail'in bir Yahudi devleti olarak ilan edilmesi, Yahudilerin dinî cemaat konumlarının siyasi bir kimliğe dönüşmesi anlamını taşımıştır. Yeni devletin sadece dinden ziyade tarih olarak Yahudilikten köklerini alan siyasi bir kimlik üzerinden kurgulanması, bu devletin güvenlik beklentisini de mevcut durumla sınırlı kılmamış^; geçmişten gelerek geleceğe dönük bir arayış olarak ortaya çıkarmıştır. Din ve tarih kendi kulvarlarında bırakılmamış; bunlar üzerinden bireye ve topluma güvenlik kaygısı hatırlatılarak; inisiyatifi ele alan güvenlikçi bir yaklaşımda birleşilmesi amaçlanmıştır. $\mathrm{Bu}$ anlayışta bir yandan Filistin topraklarındaki Yahudilerin güvenliği üzerine stratejiler kurulmaya çalışılırken, diğer yandan da Yahudi devletinin geleceğini teminat 
altına alacak bir diaspora sürece dâhil edilmeye çalışılmıştır. Yani devletin güvenlik kurgusu, mevcut güvenlik ihtiyacının ötesinde, asıl olarak geleceğe yönelik biçimde ele alınmıştır. Güvenlik kurgusunda odak noktası Filistin olurken, Yahudilerin güvenli geleceğinin kapsamına tüm diaspora dâhil edilmiştir.

Diasporanın yeni devletle güvenlik bağlamında ilişkilendirilmesi ise iki yönde olmuştur. Bunlardan ilki, göçler yoluyla gelenlerin fiilen güvenlik mekanizması içine dâhil edilerek muharip olarak kullanılması; ikincisi ise diasporada bulunan ve orada güçlü konumda olanların sahip oldukları ve olacakları güçle İsrail'in güvenliğine dolaylı katkı sağlamasıdır. Bu bakış açısından bakıldığında, İsrail' in güvenliğinin sadece devlet kurduğu Filistin'in fiziki coğrafyası bağlamında değil; dünyadaki Yahudilerin ilgisinin bu yeni devlete yönlendirilerek de kurgulandığını söylemek yanlış olmayacaktır. Yahudiliğin sürgün döneminde koruduğu din bağlamında, birliktelik hali, devletleşmeyle birlikte bir güvenlik aracı olarak devreye sokulmuştur. Bu yöntem, Yahudilerin güvenli geleceklerini belirlemek maksadıyla her türlü güç unsurunu konsolide etmelerine ve geçmişlerini yeni kurulan devlet teşkilatlanmalarına aktarmalarına imkan tanımıştır. Böylelikle Filistin coğrafyasında güvenli bir Yahudi yurdu söylemi, hem müşterek bir güvenlik arayış1/anlayışı, hem de tüm Yahudi toplumunun yeniden birleşmesine yönelik bir özlem/gurur sembolü olarak sunulmuştur.

Kurgulanan İsrail'in geleceğini güvenlik altına alma anlayışı, geçmişten geleceğe yönelik bir ele alıştır. $\mathrm{Bu}$ bakımdan güvenlik anlayış1, Yahudiliğe izafe edilebilecek tüm içeriği kendi bünyesine olabildiğince alabilme eğilimindedir. Yani güvenlik, mevcut döneme özgü güvenlik sorunlarını merkeze koymakla birlikte, asıl vurgusunu geleceğe dönük olarak yapma ihtiyacı içindedir. Tam bu nedenle, bir yandan yeni kurulan devletin bekası ele alınırken, bir yandan da bu amacı gerçekleştirecek bireyin öngörülen güvenlik konsepti dahilinde yetiştirilmesi hedeflenmiştir. İsrail Devleti'nin güvenli geleceğini sağlayacak birey; hem tarihî-dinî bağlamda geçmişiyle sık1 bağları olan, hem de geleceğin güvenlik şartlarını kestirebilen ve buna göre organize olabilen bir yapıda tasarlanmaya çalışılmıştır. $\mathrm{Bu}$ paralelde geçmişte yer alan ve Yahudilerin güvenli geleceğiyle ilişkilendirilebilecek 
172

Güvenlik Stratejileri

Y1l: 13

Sayı: 26 tüm tarihsel altyapı ön plana çıkarılmış ve topluma tekrar aşılanmıştır. Yani İsrail'in güvenliği kavramının altyapısının Yahudi toplumunun tarihsel geçmişiyle oluşturulması sağlanmıştır.

Güvenliğin gelecekle ilişkilendirilmesi bağlamında bakıldığında, siyonizm-güvenlik ilişkisinin yakın vadede elde edilmek istenenlere yönelik bir amaç olmanın yanı sıra, asıl olarak gelecekte İsrail Devleti'nin güvenliğini şekillendirmeye yönelik bir arayış olduğu görülmektedir. Bu bağlamda, homojen bir ulus oluşturulmasının güvenlik beklentisinin merkezine konulduğu söylenebilir. Dönemin gerçekliği, dünyanın her yanından gelen Yahudilerin İsrail Devleti çatısı altında birleştirilmesini; müstakbel devletin güvenliğini sağlayacak insan kaynağının da bir araya toplanmasını ve bir ortak amaç doğrultusunda harekete geçirilmesini veya her an harekete geçirilebilecek şekilde organize edilmesini gerekli kılmıştır. Bu anlayışın temel motivasyonu, düşmanla çevrilmiş olma duygusu ve reaksiyoner olmaktan başka bir seçeneğin olmadığ kabulü olmuştur. Bahse konu reaksiyonerlik sıfır toplamlı oyun bağlamında yaşam sahasının genişletilmesine yönelik kazanç elde etmektir.

Güvenliğin dışa yönelik boyutu, Yahudi yaşam sahasının genişlemesi olarak belirlenirken; içeride de bekayı sağlamaya yönelik kararlı, başka bir deyişle bekayı tek amaç olarak benimseyen bireyler yaratılması olmuştur. Zira Filistin topraklarında devletleșme öncesinde Yahudilerin yerel Arap halktan yaşanan sorunlar (1917 Balfour Deklarasyonu sonrasında belirginleşen toprak üzerindeki hak arayışları) bağlamında koparılması, geleceğe yönelik karşılıklı kimliklerin (tezantitez) esası oluşturacağı bir kurguya işaret etmiştir. Gelecek beklentileri ve çıkarları karşı karşıya gelen iki tarafın ortaya çıkması, Filistin'deki Yahudileri otomatik olarak konsolide etmiştir. Bir toplumun bir tehlike karşısında bir araya gelişinin hem bir direnç cephesi, hem de bir direnme anlayışı oluşturduğu düşünüldüğünde; Filistin'deki Yahudiler için çözümsüz bir sıfır toplamlı güvenlik sorununun, geleceğin güvenliği sağlama arayışının ve davranışının temelini oluşturduğu söylenebilir.

İsrail'in sıfir toplamlı oyun bağlamında güvenli bir gelecek arayışında gerçekleştirilmesi gereken, kendi güvenlik şartlarını güç kullanımı yoluyla karşı taraf kabul ettirmek olmuştur. Sıfır toplamlı oyun mantığının devam ettirilmesi, anılan şekilde şartların dikte 
ettirilmesi durumunu korumuştur. Tez-antitez ilişkisinin dinamik bir yapıda tanımlanması, bir yandan Yahudilerin kendilerine ait gördügü topraklardan diğer unsurların temizlenmesini kendi açılarından Güvenlik meşrulaştırmış; diğer yandan da güvenli gelecek arayışıyla örtüştürülen Stratejileri çatışmacı davranışın farklı coğrafya, dil ve kültürden gelen Yahudilerin yekpare bir toplum haline getirilebilmesini kolaylaştırmıştır. Çatışmanın sürekliliği üzerinden güvenlik arayışı, gerek insan kaynakları gerekse güvenlik araçlarının üretimi bakımından, İsrail'in sadece kendi birikimine güvenmesini de dikte etmiştir. $\mathrm{Bu}$ da güvenlik kavramının hem karşı tarafa zorla kabul ettirilecek olan, hem de İsrail'in kendini tabi kıldığı mecburiyetler bağlamında oluşturulması sonucunu üretmiştir. Böylece güvenliğin ancak güvenlikçi politika takip edilerek sağlanabileceği anlayışı devletin temel stratejisi haline gelmiştir.

Güvenlikçi politika kavramı, askerî araçların siyasi bir sorunun çözümü için öncelenmesi şeklinde genellenebilir. $\mathrm{Bu}$ yaklaşımın özünde, sorunun çözümü için karşı tarafın ortadan kaldırılmasına duyulan inanç ve gereklilik, sorunun mümkün olduğunda kısa zamanda çözülmesi arayışı ile tek taraflı çözüm şeklinin karşı tarafa zorla kabul ettirilmesi beklentisi bulunmaktadır. Karşı tarafın beklentilerinin kırılmasında ve amaçların pazarlığa açık olmadığının vurgulanmasında, güç kullanımı temel araç konumundadır. İstenilen sonucun alınabilmesi, karşı tarafin kararını çatışmadan değiştirmesini sağlayacak ezici güç üstünlügüne sahip olunmasıyla veya asimetrik güç kullanmakta tereddüt edilmemesiyle yakından ilişkilidir. Güvenlikçi politikanın doğası bir taraf-karşı taraf ilişkisini bünyesinde barındırmaktadır ve bu ilişkinin canlı tutulması güvenlikçi politikanın devamlılı̆̆ 1 için gereklidir.

Yeni kurulan devlet tez-antitez ilişkilendirmesini esas aldığından ve evrensel değerler sadece Yahudiler için anlamlandırıldığından, gelecekte güven içinde olma arayışı da kaçınılmaz duruma getirilen çatışma hâli dışındaki araçları güvenlik kavramının tanımlayıcısı olmaktan çıkarmıştır. Böylece güvenlik için çok yönlü çözüm arayışları yerine, kendi güvenliğini zorla karşı tarafa dayatan ve onun elindekileri alıp kendi hanesine yazarak güvenli bir geleceği tanımlamaya çalışan güvenlikçi bir anlayış ortaya çıkmıştır. Tehdidin sürekli olarak "yakın ve güçlü” şeklinde tanımlanması karşı taraf üzerinden şiddet araçları 
174

Güvenlik

Stratejileri

Y1l: 13

Sayı: 26

yoluyla üretilen baskının azaltılmasına imkân vermemiştir. $\mathrm{Bu}$ da güvenlikçi politikanın mevcut duruma ve gelişmelere göre yeniden düzenlenmesinden ziyade, kendini yine kendi içinden üreten yapıda kalmasının önünü açmıştır.

Güvenlik kavramının yeni devletin en öncelikli kavram haline getirilmesinde, ele geçirilen topraklarda bekanın tesis edilerek ileriye doğru bir genişlemenin sağlanması arayışı belirleyici olmuştur. İlerlemeci anlayışın ana fikri ise, elde edilen toprakların Yahudileştirilmesi ve "ne alırsak bizim olacaktır" kabulüdür. Daha fazla edinim arzusu arttıkça ve bu doğrultuda askerî başarılar kazanıldıkça, başarıyı getiren güvenlikçi anlayış da rüşdünü ispat etmiştir. Bu da kaçınılmaz olarak güvenlikçi anlayışın devletin siyasi, askerî ve ekonomik amaçlarını gerçekleştirebilecek en kullanışlı yöntem olmasını sağlamıştır. Beka için şiddet araçlarının yoğun biçimde kullanılması, her şeyin güvenlik odaklı ele alınmasına neden olmuştur. Gelecek beklentisi güvenlik esaslı tanımlanınca, güçlü olup taviz vermeye yanaşmak istemeyen güvenlikçi bir politika tartışmasız tek yön konumuna gelmiştir.

İsrail Devleti'nin sınırlarının esnetilmeye müsait şekilde gelecek nesillerin zihnine yerleştirilmesi, sadece mevcut beka sorunun aşmanın yöntemi olarak benimsenmesinin değil; geleceğin de güvenlikçi politikanın etkisinde kalmasının önünü açmıştır. Zira sınırların tanımsız bırakılması, ileriye doğru genişleme isteğini canlı tutmuştur. $\mathrm{Bu}$ isteğin sıfır toplamlı oyun içinde güç kullanımından başka yolla gerçekleştirilmesi ihtimali olmadığından, yollar yine güvenlikçi politikaya çıkmıştır. Güvenlikçi gelecek kabulüne sabitlenmenin nedenlerinden biri de, savaşta ülkesi için fedakârlık yapan neslin bir idol haline getirilmesi olmuştur. Güvenlikçi yaklaşım sonraki nesillere daha güvenli bir gelecek ülküsü lanse ederken; mevcut nesile ise realist şekilde bir var olma veya yok olma tercihi sunmuştur. Yahudi toplumunun bu düşünce ve duygu çemberi içinde tutulması, bekanın bir gerekliliği olarak konumlandırılmıştır. Bekanın askerî güç kullanılarak sağlanması, güvenlikçi politikanın olması gereken bir sonucu olarak ele alınırken; daha geniş sınırlara sahip daha güvenli bir Yahudi devleti beklentisinde ise umutların gerçekleşmesini hızlandıran katalizör olarak kullanılmıştır. 
Güvenlikçi karakteri süreklilik gösterecek bir politik altyapı oluşturulması, devletin geleceğinin güç kullanımıyla belirlenmesini de kaçınılmaz kılmıştır. Bu sonuç, devletin bekasının sağlanmasının beraberinde meydana gelen bir yan ürün şeklinde değil, yaşam alanının genişletilmesinin bir gerekliliği biçiminde ele alınmıştır. Güvenlikçi politikaya altyapı oluşturan çatışma hâli, bir yandan kazanımlara imkân tanırken, diğer yandan da yeni kurulan devletin var olma ve varlığını devam ettirme reflekslerini canlı tutmuştur. Aynı bağlamda, çatışma sonucu kazanılmış askerî başarılar üzerinden kurulmuş bir devletin gelecek nesilleri daha derinden etkileyecek ve bağlayacak mitler oluşturulmasına zemin sağlaması da, güvenlikçi politikanın bir amacı olarak karşımıza çıkmıştır.

Devlete ve topluma dair tüm süreçlerin planlayıcı ve uygulayıcısı olarak her şeyin üzerinde konumlandırılan "mamlachtiut" anlayışının yöntemi olan tepeden inmeci ve tek tipçi yaklaşım, güvenlik politikasını güvenlikçi politikaya dönüştüren ve devamlılığını sağlayan bir etmen olarak görülebilir. Bir yandan "mamlachtiut" kurgusunun yukarıdan uyguladığ 1 basınç bireyi bu kurgusu içinde eritirken; diğer yandan dinin ve tarihin empoze ettiği Siyonizm ülküsü de bireyi dünyayı sadece güvenlikçi açıdan algılamasını sağlayan bir fasit daireye sıkıştırmıştır. "Mamlachtiut" anlayışın biçimlendirdiği güvenlikçi politika, çatışma hâlinin bir tercih değil de bir seçeneksizlik olduğunu Yahudi toplumuna kabul ettirmeyi esas alırken; her bireyin varlığını devletin devamlılı̆̆ıyla doğrudan bağlantılı hale getirmiştir. Böylece her Yahudi birey, güvenlikçi politikanın etkin (savaşçı) bir nesnesi olarak konumlandırılmıştır. Çatışma hâli, bir yandan iç muhalefetin oluşmasını engellemiş; diğer yandan da göç yoluyla gelenlerin bir an önce mevcut duruma ve toplumsal kabullere uyum göstermesini sağlamıştır. Yani çatışmanın beslediği güvenlikçi politika aynı zamanda etkin bir entegrasyon programı olarak da işlev görmüştür. Göçlerle büyüyen Filistin'deki Yahudi toplumunun güvenlik kaygısı, güvenlikçi politika üzerinden devletin güvenli geleceğine dönüştürülmüştür.

Kurgulanan güvenlikçi politika, devleti kurmanın ötesinde kuruluşun sonrasındaki dönemde de hem iç gelişmelere, hem de dış gelişmelere yönelik karar alma süreçlerinin de belirleyicisi olmaya devam

Güvenlik Stratejileri

Y11: 13

Sayı: 26 
176

Güvenlik Stratejileri

Y11: 13

Say1: 26 etmiş̧tir. Bunun temel nedeni, askerî araçların gücü elde etmenin/elde tutmanın birincil aracı olma konumunu koruması ve ötekileştirmeye Yahudileri konsolide etme görevi yüklenmesidir. Bahse konu bu iki husus, geçmişten geleceğe doğru tanımlı bir yaşam ve düşünüş tarzının da teminatını oluşturmuştur. Bu iki temel korunduğu sürece güvenlikçi politikanın varlığının ve etkisinin devam edeceği söylenebilir.

\section{Sonuç}

Yahudiler tarih boyunca birlikte olma ve güven içinde bir hayat yaşayabilme özlemi içinde olmuştur. Yaşadıkları sürgün ve yok edilme tecrübeleri, güvenlik arayışlarını canlı tutmuştur. $\mathrm{Bu}$ arayış dünyada dağıldıkları diğer milletler içinde bulundukları toplumun şartları ve imkânları bağlamında gerçekleştirilmeye çalışılmıştır. Ancak yekvücut olamadıkları için beklentileri ortak bir gelecek programına dönüşmemiş, sadece "gelecek yıl Kudüs'te" şeklinde dua, istek ve temennilerine yansımıştır.

İsrail Devleti'nin kuruluşu bir araya gelmenin yanı sıra, kendi geleceklerini kendileri belirleme inisiyatifinin de Yahudilere geçmesini sağlamıştır. Tarihten süzülüp gelen en büyük sorun olan güvenlik endişesi, kurulan devletin temel taşını oluşturmuştur. Devletin yaşatılması mücadelesi de geçmişten getirilen kaygıların etkisinde kalmıştır. Böylece güvenlik ve güvenlikçi yaklaşımlar bir yaşam şekline dönüşmüştür. Kendi geleceklerini belirleme inisiyatifinin elde edilmesi, güvenlikçi anlayışın gelecek kurgusuna dönüşmesinin önünü açmıştır. Yaşanan çatışmalar nedeniyle geçmişten getirilen güvenlik endişesi devletleşmeyle birlikte ortadan kalkmadığından, geçmişin tüm endişe ve korkuları silahlı gücün elde edilmesiyle sahaya yansitılmıştır. Tarih boyunca kendini besleyip büyüten güvenlik endişesi güç unsurlarına sahip olunmasıyla güvenlikçi politikaya dönüşmüştür.

$\mathrm{Bu}$ açıdan bakıldığında Yahudiler geçmişi bir türlü geride bırakamadığı ve devlet genişlemeye yönelik tanımlandığı için İsrail'in güvenlikçi temelde yükselen bir Yahudi devleti olduğu söylenebilir. Devletin kurulduğu dönemde varoluş mertebesinde bir güvenlik tehdidinin bulunduğu bir gerçektir. Ancak tehlikenin önemli ölçüde bertaraf edilmesinden sonra da güvenlikçi politikanın artan dozda 
devam ettirilmesi iki nedene dayandırılabilir: a) geçmişin güvenlik kaygılarına bir daha ne pahasına olursa olsun dönülmemesi, b) güvenlik duygusunun geliştirilebilmesi için askerî gücün maksimize Stratejileri edilmesi, daha fazla Yahudinin bir araya getirilmesi yoluyla güvenlik Y1l: 13 duygusunun büyümesinin sağlanması ve yaşam alanının düşmanlar ile arasında engel oluşturacak şekilde genişletilmesi. Bu iki husus, güvenlik

\section{Summary}

This study examines whether the Jewish state established in the name of the State of Israel has transformed from a search for a safe homeland to a security-minded state. In this frame, the infrasructure that includes the state's constructional essence, its inspiration, its living space and its social composition is set forth in a fashion of providing a ground for founding a state that will be safety guarantee of Jews. And an analysis is conducted through this scope. The study is based on the ideas, decisions and actions of a Jewish political and military elite under the active leadership of David Ben Gurion in the construction of the state fiction. Because the study focuses on the relationship between a historical survival aspiration shaped by the conflict environment and the nationalization, it covers the immediate before and after of the foundation of the state in which the basic parameters concerning the State of Israel are determined.

The study is based on the fact that Jews have lived a life of security worries throughout their history and that they have found their solution in fictioning their own state. The frame of the study is drawn by not only the security anxiety which has paved the way for a state, but also the anxiety that has opened an gate for a security-minded policy which dominates the state's operating system. In order to be able to draw the borders of the security policy, the process of becoming a state is considered and the need for the state is determined. 
178

Güvenlik

Stratejileri

Y11: 13

Say1: 26
Once the need for the state is identified with the search for security, then what is meant the security for Jews in state structure is revealed.

The structure that is conceived as assurance of a safe future for Jews is treated as sub-components. In the section of Structural Essence of the State, it is determined what is the structure that will enable to bring Jewish history and security needs together. In the section of Inspiration of the State, how the concept of Zionism brings together the individual and the state together in security duties is discussed. In the section of the State of Life, the spatial dimension of the concept of security, namely the matter of gaining more territory, for Jews is examined. In the section of Social Components of the State, the concept of security is taken into account in terms of how Jews deals with the others living in Palestine.

Once the framework for the security of the Jewish state is drawn, then it is analyzed whether the scope fictioned for the sate is a safe homeland or a security-minded state. The conclusion reached in the analysis is that security anxiety, which is the biggest problem in their history, has formed the foundation stone of the state. In the context of the conclusion reached in the study, the struggle for survival of the state has also influenced by the past expectations and anxiety that may create any security perception. And in the very end, the concept of security and its related approaches have become a way of life. Getting the initiative of determining their own future has opened the way for the understanding of security that turns into a future fiction. As the security problems brought about by the conflicts have not gone along with the foundation of the state, all the anxieties and worries of the past have been reflected on the field after having military might. The security concern nourished throughout history has turned into a security policy in wake of having the power and military elements.

In the study, it was also found that maintaining security policy at an increased military dose has based on two factors: a) no return to security anxieties of the past whatever the cost is and b) maximizing the military power to develop security sentiment, gathering of more Jews in Palestine to increase the sense of security and expanding of the 
living space in order to create an obstacle between the Jews and its enemies. In the context of the two issues mentioned, it is concluded that the security-related actions are realist, pragmatist and materialistic in the way of the security policy, but has idealistic and religious features in order to mobilize the Jewish community.

\section{Kaynakça}

\section{Kitap}

ADAM Herbert and Kogila Moodley, Seeking Mandela: Peacemaking Between Israelis and Palestinians, Temple University Press, Philadelphia, 2005.

BAR-ON Mordechai, In Pursuit of Peace: A History of The Israeli Peace Movement, United States Institute of Peace, Washington D.C., 1996.

BEN-AMI Slomo, Scars of War, Wounds of Peace, Oxford University Press, Oxford, 2006.

BEN-GURION David, Rebirth and Destiny of Israel, Polyglot Press, New York, 1954.

BERRY Mike and Greg Philo, Israel and Palestine: Competing Histories, Pluto Press, London, 2006.

COMAY Joan, Who is Who in Jewish History, Routledge, New York, 2005. COOK Jonathan, Disappearing Palestine: Israel's Experiments in Human Despair, Zed, London, 2008.

FELDSTEIN Ariel L., Ben-Gurion, Zionism and American Jewry 1948-1963, Routledge, New York, 2006.

FLAPAN Simha, The Birth of Israel: Myths and Reality, Croom Helm, London, 1987.

GLUSKA Ami, The Israeli Military and The Origins of 1967 War: Government, Armed Forces and Defence Policy 1963-1967, Routledge, New York, 2007.

HAHN Peter L., Caught in Middle East: US Policy Towards The ArabIsraeli Conflict 1945-1961, The University of North Carolina Press, Chapel Hill, 2004. 

HALPER Jeff, An Israeli in Palestine: Resisting Dispossesion, Redeeming Israel, Pluto Press, London, 2008. HARMS Gregory and Todd M. Ferry, The Palestine-Israeli Conflict, Pluto Press, London, 2008.

Say1: 26 HART Alan, Zionizm: The Real Enemy of The Jews, World Focus Publishing, United Kingdom, 2005.

HELLER Joseph, The Birth of Israel 1945-1949: Ben Gurion and His Critics, University of Florida Press, Gainnesville, 2003.

JONES Clive and Emma C. Murphy, Israel: Challenges to Identity, Democracy and The State, Routledge, New York, 2002.

KAPLAN Eran, The Jewish Radical Right, The University of Wisconsin Press, Wisconsin, 2005.

KARMI Ghada, Married to Another Man: Israel's Dilemma in Palestine, Pluto Press, London, 2007.

KARSH Efraim, Israel: The First Hundred Years, Frank Cass, London, 2004.

LOCHERY Neil, Why Blame Israel?: The Facts Behind The Headlines, Icon Books, Cambridge, 2004.

MASALHA Nur, Imperial Israel and The Palestinians, Pluto Press, London, 2000.

MORRIS Benny, Israel's Border Wars, 1949-1956, Clarendon Press, Oxford, 1993.

MORRIS Benny, Righteous Victims: A History of The Zionist-Arab Conflict, 1881-2001, Knopf, New York, 1999.

NASR Kameel B., Arab and Israeli Terrorism: The Causes and Effects of Political Violence 1939-1999, Mc Farland and Company Publishers, North Carolina, 1997.

OHANA David, Political Theologies in The Holy Land, Routledge, New York, 2010.

PENSLAR Derek J., Israel in History, Routledge, New York, 2007.

ROTENSTREICH Nathan, Zionism: Past and Present, State University of New York Press, Albany, 2007.

Ruling Palestine: A History of The Legally Sanctioned JewishIsareli Seizure of Land and Housing in Palestine, The Center for Housing Rights and Evictions (COHRE) - Source Center for Palestine 
Residency and Refugee Rights (BEDIL) Publications, 2005. Our Time, Knopf, New York, 1986.

SELIKTAR Ofira, New Zionism and The Foreign Policy System of Israel, Croom Helm, Beckenham, 1986.

SHAHAK Israel, Jewish History, Jewish Religion, Pluto Press, London, 1994.

SHEFFER Gabriel, Moshe Sharett: A Biography of A Political Moderate, Clarendon Press, Oxford, 1996.

SHLAIM Avi, Conclusions Across The Jordan, Colombia University Press, New York, 1988.

SHLAIM Avi, The Iron Wall: Israel and Arab World, W.W. Norton, New York, 2001.

SOENTENDORP Ben, The Dyamics of Israeli-Palestinian Relations, Palgrave McMillan, New York, 2007.

TAL David, The War in Palestine 1948: Strategy and Diplomacy, Routledge, New York, 2004.

TEVETH Shabtai, Ben-Gurion and the Palestinian Arabs: From Peace to War, Oxford University Press, Oxford, 1985.

TEVETH Shabtai, Ben-Gurion: The Burning Ground, 18861948, Houghton Mifflin, Boston, 1987.

THOMAS Baylis, The Dark Side of Zionism, Lexington Books, Plymouth, 2009.

TOVY Jacob, Israel and The Palestinian Refugee Issue, Routledge, New York, 2014.

WOODS Patricia J., Judicial Power and National Politics, State University of New York Press, Albany, 2008.

WYMAN David S., The Abandonment of The Jews: America and Holokost, Pantheon Books, New York, 1984.

ZERTAL Idith, From Catastrophe To Power: Holokost Survivors and The Emergence of Israel, University of California Press, California, 1998. ZERTAL Idith, Israel's Holokost and The Politics of Nationhood, Cambridge University Press, Cambridge, 2010. 
BEN-RAFAEL Eliezer, "The Kibbutz in 1950s: A Transformation of Identity”, S. Illan Troen, Noah Lucas (ed.), Israel: The First Decade of Independence, State University of New York Press, Albany, 1995. CARMI Shulamit and Henry Rosenfeld, "The Time When The Majority in The Israeli Cabinet Decided 'Not to Block The Possibility of The Return of The Arab Refugees' and How and Why This Policy Defeated", Michael Saltman (ed.), Land and Territoriality, Berg, Oxford, 2002.

DON-YEHIYE Eliezer, "Political Religion in A New State: Ben Gurion's Mamlachtiyut", S. Illan Troen, Noah Lucas (ed.), Israel: The First Decade of Independence, State University of New York Press, Albany, 1995.

DRORI Ze'ev, "Utopia in Uniform”, S. Illan Troen, Noah Lucas (ed.), Israel: The First Decade of Independence, State University of New York Press, Albany, 1995.

GORNY Yosef, "Klal Yisrael: Halakha to History", Eliezer BenRaphael, Yosef Gorny, Yaacov Roi (ed.), Contemporary Jewries, Brill, Leiden, 2003.

GORNY Yosef, "Zionist Voluntarism in The Political Struggle: 19391948”, Jewish Political Studies, 1990, Vol. 2, No. 1-2.

PELEG Ilan, "Israel As A Liberal Democracy: Civil Rights in The Jewish State", Review Essays in Israel Studies, State University of New York Press, Albany, 2000.

SCHROETER Daniel J., "A Different Road to Modernity: Jewish Identity in The Arab World", Howard Wettstein (ed.), Diasporas and Exiles, University of California Press, Berkeley, 2002.

SLESS Jonathan, "Blocking Peace: Britain and Israeli-Jordanian Conflict 1949-1951", (Efraim Karsh ed.), Israel: The First Hundred Years, Frank Cass, London, 2004.

TROEN S. Illan and Noah Lucas, "An Introduction to Research on Israel's First Decade", S. Illan Troen, Noah Lucas (ed.), Israel: The First Decade of Independence, State University of New York Press, Albany, 1995. 
ZUREIK Elia, "Constructing Palestine Through Surveilence Publications, California, 2007.

\section{İnternet}

"The Declaration of The State of Israel - May 14, 1948", Israel Ministery of Foreign Affairs, http://www.mfa.gov.il/mfa/foreignpolicy/ peace/guide/pages/declaration\%20of\%20establishment\%20of\%20state \%20of\%20israel.aspx (Erişim Tarihi: 04.05.2017).

ISSEROFF Ami, "A Zionist Manifesto: We Must Make The Change That We Seek", ZioNation-Progressive Zionism and Israel Web Log, 29 February 2008, http://www.zionism-israel.com/log/archives/ 00000500.html (Erişim Tarihi: 15.05.2017)

PERES Shimon, "Pivotal Movements", The Jewish Week, 29 November 2011, http://www.thejewishweek.com/special_sections/ text_context/pivotal_moments (Erişim Tarihi: 15.04.2017) 

